\title{
Sulama Suyu Tuzluluğunun Biberde (Capsicum annuum) Farklı Gelişme Dönemlerinde Bazı Verim Parametrelerine Etkisi
}

\author{
Engin YURTSEVEN ${ }^{(1)}$, Ahmet ÖZTÜRK', Abdullah KADAY!FÇI', Bülent AYAN' \\ Geliş Tarihi : 11.01.1996
}

\begin{abstract}
Özet : Sulama suları ile toprağa iletilen tuzlar toprağı yada bitkiyi etkileyerek verimde azalmalara neden olurlar. Bu azalma miktarı bitkinin tuza dayanımı ile yakından ilgilidir. Bitkilerin tuza dayanımları ise farklı gelişme dönemlerinde farkı oimaktadır. Bu çalışmada ekonomik değeri yüksek olan sivri biberde, çimlenme ve fide oluşumu dőnemleri ile gelişme dönemlerindeki sulama suyu tuzluluklarının, bazı verim parametrelerine olan etkileri araștırılmıştır. Serada saksı denemeleri biçimde yapılan çalışmalar sonucunda; çimlenmeye ve fide biomas değerine $3.0 \mathrm{dS} / \mathrm{m}^{\prime} l i k$ tuzluluk dozzeyinin önemli bir etkisi olmadığı, fide boylarının ise bu tuzluluk düzeyinde \%13 kadar arttığı gözlenıniştir. Bitki geliş̧me dönemlerindeki tuzluluk düzeylerinin ise bitki verimi ve biomas'ını \%1, meyve boyu ve meyvede toplam kül değerlerini \%5 düzeyinde etkilediği gözlenmiştir. Yaprak ve dallardaki toplam kül değerleri ise deneme konularından etkilenmemiştir. Ayrıca ele alınan verim parametrelerinin hiçbirisinde faktörler arası etkileşim (interaksiyon) onemli bulunmamıștır.
\end{abstract}

Anahtar Kelimeler : tuzluluk, biber, tuzluluk-verim ilişkisi, çimlenmede tuzluluk

The Effect of Irrigation Water Salinity on Some Yield Parameters of Pepper (Capsicum annuum) During Different Growing Periods

Abstract : The salts transported to the soil with irrigation water effect the crop yield in different ways. It can effect soil physical conditions or effect directly to the crop with its ions which are toxic to the crop. In general yield decrease of the crop is closely related to the salt tolerance. In this greenhouse experiment, the effect of irrigation water salinity on some yield parameters of pepper were investigated for different growing periods. The results showed that; $3.0 \mathrm{dS} / \mathrm{m}$ salinity level did not effect the germination and the seedling biomass contents, but increased to the seedlings heights as $13 \%$. The salinity during the growing period, however, decreased the yield and the biomass content of the fruit. The fruit height and the total ash contents were also affected by the salinity. The total ash contents of leaves ant petioles, however, were not affected by the salinity at the level of $\% 5$. The interactions of the experimental factors were not statistically important on the yield parameters studied.

Key Words : Salinity, pepper, salinity-yield relation, salinity on germination

\section{Giriş}

Sulama suları ile toprağa ilettiğimiz tuzlar, toprak çözeltisi içerisinde birikerek üzerinde yetiştirilen bitkiyi farklı biçimlerde etkilerler. Bu tuzlar toprak fiziksel özelliklerini etkileyebileceği gibi, doğrudan bitki üzerine toksik yani zehirli etki de yapabilirler ve sonuçta verimde azalmalar oluşacaktır. Yetiştirilen bitkinin veriminde görülecek azalmalar, çözeltinin konsantrasyonuna baḡlı olduğu kadar, bitkinin tuza dayanımı ile de ilgilidir. Tuza dayanımı fazla olan bitkiler yüksek tuzluluklarda dahi verimde önemli azalmalar oluşturmazken, tuza dayanımı fazla olmayan bitkiler, düşük tuzluluklarda dahi verimde önemli azalmalar gösterebilirler.

Bitkilerin tuza olan dayanımları, gelişme dönemi ile yakından ilgilidir. Genelde tüm bitkiler çimlenme ve ilk gelişme devrelerinde tuza daha duyarlıdırlar. $\mathrm{Bu}$ dönemdeki tuzluluk etkilenmeleri, bitkinin ileriki dönemlerinde yetersiz gelişmesine neden olabilecektir.

Biber (Capsicum annuum), tuza dayanımı orta hassas olan bir kültür bitkisidir. Ayers (1977), biber bitkisinin verimde oluşturacağı azalmaların 1.0-1.5 dS/m tuzluluk düzeyinde bașlayacağını, $\quad E C_{i}=3.4 \mathrm{dS} / \mathrm{m}$ düzeyinde ise verimde yaklaşık $\% 50$ kadar bir azalmanın beklenmesi gerektiğini belirtmiştir. Smitt ve Cobb (1991) biber tohumlarında 10 ila $100 \mathrm{mM}$ tuz konsantrasyonunda çimlenmede bir azalma görmemişken, 200-300 mM arasında ancak $\% 5^{\prime}$ lik bir çimlenme gözlemlemişlerdir. Sonneveld ve Burg (1991) domates, biber ve salatalıkta yaptıkları çalışmalarda, verimin azalmaya başladığı eşik değerini 2.3-3.5 dS/m olarak, daha sonraki her $1 \mathrm{dS} / \mathrm{m}$ tuzluluk artışına karşılık azalma miktarlarının ise \%2.3. 7.6 arasında olduğunu belirtmişlerdir. Öztürk (1994), dolmalık biberde yaptığı çalışmada ise $3 \mathrm{dS} / \mathrm{m}$ tuzluluk düzeyinde oluşan oransal verim değerlerinin \%59.6$\% 67.3$ arasında olduğunu belirtmiștir.

Bu çalışmanın amacı, sivri biberde çimlenme ve fide oluşumu ile sonraki gelişme dönemlerindeki tuzlulukların bazı verim parametrelerine olan etkilerinin serada saksı denemeleri şeklinde belirlenmesidir.

\section{Materyal ve Yöntem}

Biberde değişik tuzluluk düzeylerındeki sulama sularının farkli gelişme dönemlerinde bazı verim parametrelerine olan etkilerini ortaya koymak amacıyla 
planlanmiş olan bu çalışma serada saksi denemeleri şeklinde yürütölmüştür.

Biber tohumları, boyutiari $1 \times 1 \times 0.15 \mathrm{~m}$ olan ve içerisine $1 / 3$ tarla toprağı, $1 / 3$ kum ve $1 / 3$ yanmış-elenmiş ahır gübresi kanşımı konan ahșap fide yetiştirme kasalarına, tüm tekrarlamalara 100 adet olmak üzere ekilmişlerdir, Çimlenen tohum sayıları ile yetiştirilen fidelerin boyları ve kuru madde (Biomass) değerler belirlenmiştir. Çimlenme ve fide oluşumu dönemlerindeki tuzluluk etkilerini ortaya koyabilmek amaciyla 0.25 (kontrol) ve $3.0 \mathrm{dS} / \mathrm{m}$ tuzluluk düzeyleri ( $F_{0}$ ve $F_{1}$ ) göz önüne alınmıştır. Fideler 5 hafta sonunda örneklenerek fide boyları ve $65^{\circ} \mathrm{C}$ de kuru madde (biomas) değerleri belirlenmiștir. Çimlenme ve fide oluşumu dönemlerinde tuzluluk etkilerinin belirlenmesi çalışmaları 4 tekrarlamalı olarak yürütülmüş, fidede biomas değerlerinin belirlenmesi amacıyla ise tekrarlamalar içerisinden toplam 10'ar adet örnekleme yapıımıştır.

Biberde, sonraki gelişme dönemlerinde tuzluluk etkilerinin belirlenmesi amaciyla, tuzsuz $\left(F_{0}\right)$ ve tuzlu $\left(F_{7}\right)$ koșullarda yetiştirilen biber fideleri tesadüfi olarak seçilerek, $20 \mathrm{~cm}$ yüksekliğinde ve $21 \mathrm{~cm}$ çapındaki (No9) plastik saksılara dikilmişlerdir. Bu saksılar içerisine eşit miktarlarda ve olabildiğince doğal hacim ağırlığına eşit olarak, hava kurusu yapıldıktan sonra $4 \mathrm{~mm}$ elekten elenmiş tarla toprağı yerieştirilmiştir. Denemelerde kullanilan toprak Ankara Sarayköy çevresinden sağlanmıştır. Bu topraklar potasyumca zengin, buna karşın organik madde ve fosforca fakir, birikime uğramıș azonal kil bünyeli topraklardır. Topraklar içerisine verimlilik analizine göre belirlenmiş miktarlarda yanmışelenmiş ahır gübresi lle azotlu ve fosforlu gübre llave edilmiştir.

Biberde sulama suyu tuzluluğunun bitki gelişimine ve verimine olan etkilerini ortaya koyabilmek için 4 tuzluluk düzeyi seçilmiștir. Bunlar $T_{0}=0.25 \mathrm{dS} / \mathrm{m}$ (kontrol), $T_{1}=1.5 \mathrm{dS} / \mathrm{m}_{1} T_{2}=3.0 \mathrm{dS} / \mathrm{m}$ ve $T_{3}=6.0 \mathrm{dS} / \mathrm{m}$ dir. Bu şekilde denemeler tesadúf parsellerinde faktöriyel düzende 3 tekrarlamali olmak üzere $(2 \times 4 \times 3=24$ saksi) olacak biçimde kurulmuştur. Sulama suyu olarak Ankara şehir şebeke suyu kullanılmıştır. Daha tuzlu konuların oluşturulmasında ise erirlilikleri yüksek olan sodyum bikarbonat $\left(\mathrm{NaHCO}_{3}\right)$, kalsiyum klorür $\left(\mathrm{CaCl}_{2}\right)$ ve magnezyum sülfat $\left(\mathrm{MgSO}_{4}\right)$ tuzları kullanilmıştır. Genel olarak Ca ve Mg'un toprak fiziksel özellikleri üzerine olan etkileri benzer olduğundan (poonia ve $\mathrm{Pal}$, 1979), bu tuzların eklenen bazda oranları $1 / 1$ olarak alınmıştır. Sulama sularının SAR değerleri kontrol konusu SAR değeri alan 0.35 dolaylarında korunmuștur. Sulama suyu miktari ve sulama zamani, saksılar belli periyotlarda tartılarak ağırlık esasına göre belirlenmiştir.

Biberde tuzluluğun gelişme ve verim üzerine olan etkilerini ortaya koyabilmek amacıyla bitki boyu, meyve boyu, meyve yaș ağırlığı (bitki verimi), meyve biomas değeri, meyve, yaprak ve dallarda kül analizleri yapilmıştır. Toprak fiziksel analizlerinden bünye Bouyoucos (1951)'e, diğer fiziksel analizler Anonymous (1954)'e, bitki analizleri Kacar (1972)'ye, denemelerden elde edilen bulguların değerlendirilmesi ise Yurtsever (1984)'e göre yapılmiştır.

\section{Bulgular ve Tartışma}

Denemelerde kullanılan toprak materyaline ilişkin verimlilik ve fiziksel analiz bulguları Çizelge 1'de verilmiştir. Toprak kil bünyeli olup yarayışılı su tutma kapasitesi $32.3 \mathrm{~mm} / 30 \mathrm{~cm}$ dir. Toprak bitki besin maddelerinden yalnızca potasyum açısından zengindir. Buna karşın organik madde ve fosfor kapsamı düşüktür.

\section{Çimlenme ve fide gelişmi bulguları}

Çimlenme ve fide gelişimine tuzluluğun etkisini inceleyebilmek amacıyla, çimlenen tıhum sayılan ile 5 hafta sonunda fide boyları ve fide kuru madde (biomas) değerleri belirlenmiştir. Elde edilen bulgular Çizelge 2 ve 3 'de verilmiştir.

Çizelgelerden de izlenebileceği gibi, ele alınan tuzluluk konularında çimlenen tohum sayılarında önemli bir fark ortaya çikmamıştır. Bir başka deyişle $3 \mathrm{dS} / \mathrm{m}$ tuzluluk düzeyi biberde çimlenme üzerine etkili olmamıştır. Fide boylarında ise tuzluluğun artması ile yaklaşık \%13 kadar bir artış gözlenmiştir. Fide biomas değerleri ùzerine de yine ele alınan tuzluluk konularının bir farklılık yaratmadiğı gözlenmiştir. Kontrol ve $3 \mathrm{dS} / \mathrm{m}$ tuzluluk duzeyinde elde edilen ortalama biomas değerleri sırasıyla $\% 89.63$ ve $\% 89.77$ olmuştur.

\section{Bitki gelişimi bulguları}

Biberde sulama suyu tuzluluğunun bitki gelişimi ve bazı verim parametrelerine olan etkilerini belirleyebilmek amacıyla bitki boyu, meyve boyu gibi fiziksel parametrelerle, meyve verimi, meyvede biomas düzeyleri ve bitki dal ve yaprakları ile meyvede toplam kül değerleri incelenmiştir.

Tuzluluk konuları için elde edilen bitki verimleri (meyve yaş ağırlıkları), meyve boyları ve meyve biomas değerleri Çizelge 4 'de verilmiştir.

Yapilan varyans analizleri sonucunda, gelişme dönemindeki sulama suyu tuzluluklarının hem bitki verimini ve hem de meyve boyu ile meyvedeki biomas değerlerini önemli düzeylerde etkiledikleri görülmüştür. Bu etkilenme duzeyleri verimde ve meyve biomas deg̃erlerinde $\% 1$ iken, meyve boyunda $\% 5$ önemlilik düzeyinde olmuştur. Bu etkilenmeler aynı zamanda Şekil 1,2 ve 3 'de de görülebilmektedir. Tuzluluk düzeylerinin artmasıyla bitki verimi ve meyve boyu değerlerinin her ikisinde de sirasıyla $\% 61$ ve $\% 13$ oraninda azalmalar oluşurken, meyve biomas değerlerinde yaklașık \%11'lik bir artma meydana gelmiştir. Çimlenme ve fide oluşumu dönemindeki tuzluluk ise, daha sonraki bitki gelişimi ve verimi üzerine, yukarıdaki parametreler açısından önemli bir etkide bulunmamiştır. Benzer şekilde deneme faktörleri arasındaki interaksiyon da önemsizdir. Bunun anlamı ise, gelişme döneminde bitkinin etkisinde kaldığı tuzluluk düzeyleri nedeniyle meydana gelen farklıliklar, çimlenme ve fide oluşumu döneminde bitkinin etkisinde kaldığı tuzluluk etkilerinden bağımsız olarak olușmuștut.

Aynı parametreler için yapılan Duncan analizi sonuçları Çizelge $5^{\prime}$ de verilmiştir. 
Biberde tuzluluktan ötürü biriktirilen mineral madde miktarlarındaki değişimin belirlenebilmesi amacıyla meyvede ve bitkinin dal ve yapraklarında toplam kül analizleri yapılmıştır. Bu analizler sonucu elde edilen değerler incelendiğinde, sulama suyu tuzluluklarının her iki dönemde de yalnızca meyvede biriktirilen mineral madde miktarı üzerine $\% 5$ önemlilik düzeyinde etkide bulundukları gözlenmiştir. Yaprak ve dallarda elde edilen kül miktarları üzerine ise deneme konularının istatistiksel bakımdan etkileri olmamıştır. Meyvedeki kül miktarına sulama suyu tuzluluklarının etkileri, gelişme dönemleri olarak biribirinden bağımsız olmuştur. Deneme faktörleri arasında etkileşim (interaksiyon) önemsizdir. Bir başka deyişle çimlenme ve fide oluşumu döneminde tuzluluğun artması ile toplam kül miktarında oluşan azalmalar, daha sonraki gelişme dönemlerinde bitkiyi etkileyen tuzluluk düzeyleri sonucu kül miktarında meydana gelen azalmaları etkilememiştir (Şekil 4).

Bitki gelişimi ile ilgili olarak incelenen bir diğer parametre ise bitki boyu olmuştur. Gelişme dönemi içerisinde 34., 55. ve 112. günlerde, her saksıdaki bitki boyları ölçülmüştür. Bu değerler Şekil 5 'de grafiklenmiştir. Bitki boyları gerek $F_{0}$ gereksede $F_{1}$ konularında, $T_{0}$ 'dan $T_{3}{ }^{\prime} e$ doğru hemen hemen aynı değişim özelliğini göstermiştir: Bitki boyları $T_{1}$ düzeyinde bir miktar artma gösterirken, daha sonraki tuzluluk düzeylerine azalmaktadır. Bu değişim aynı karakterde olmakla beraber, genelde bitki boyları $F_{1}$ konularında $F_{0}$ 'a göre bir miktar daha düşük elde edilmişlerdir.

Çizelge 1. Deneme toprağı verimlilik ve fiziksel analiz bulguları.

\begin{tabular}{|c|c|c|c|c|c|c|}
\hline $\begin{array}{c}\begin{array}{c}\text { Su ile } \\
\text { doymuşluk }\end{array} \\
(\%)\end{array}$ & $\begin{array}{c}\text { Toplam tuz } \\
\text { (\%) }\end{array}$ & $\begin{array}{c}\text { Doymuş } \\
\text { Toprakta } \\
\text { pH }\end{array}$ & $\begin{array}{c}\text { Kireç } \\
\mathrm{CaCO}_{3} \\
(\%)\end{array}$ & $\begin{array}{c}\text { Yarayışlı } \\
\text { Fosfor } \\
\mathrm{P}_{2} \mathrm{O}_{5} \\
\text { (Kg/da) }\end{array}$ & $\begin{array}{c}\text { Yarayışlı } \\
\text { Potasyum } \\
\mathrm{K}_{2} \mathrm{O} \\
(\mathrm{Kg} / \mathrm{da})\end{array}$ & $\begin{array}{c}\begin{array}{c}\text { Organik } \\
\text { Madde }\end{array} \\
(\%) \\
\end{array}$ \\
\hline 105 & 0.095 & 7.81 & 7.50 & 2.15 & 159.3 & 1.55 \\
\hline $\begin{array}{l}\text { Hacim } \\
\text { Ağırlığı } \\
\left({\left.\mathrm{g} / \mathrm{cm}^{3}\right)}\right.\end{array}$ & $\begin{array}{c}\text { Tarla } \\
\text { Kapasitesi } \\
(\%)\end{array}$ & $\begin{array}{c}\text { Solma } \\
\text { Noktası } \\
(\%)\end{array}$ & $\begin{array}{l}\text { Kum } \\
\text { (\%) }\end{array}$ & $\begin{array}{l}\text { Silt } \\
\text { (\%) }\end{array}$ & $\begin{array}{l}\mathrm{Kil} \\
\text { (\%) }\end{array}$ & $\begin{array}{l}\text { Bünye } \\
\text { Sinifi }\end{array}$ \\
\hline 1.14 & 33.0 & 25.3 & 9.6 & 32.3 & 58.1 & C \\
\hline
\end{tabular}

Çizelge 2. Tuzluluk konuları için çimlenen tohum sayıları ve fide boyları.

\begin{tabular}{|c|c|c|c|c|c|c|c|c|c|c|}
\hline & \multicolumn{5}{|c|}{$F_{0}\left(E C_{i}=0.25 \mathrm{dS} / \mathrm{m}\right.$, kontrol $)$} & \multicolumn{5}{|c|}{$F_{1}\left(E C_{i}=3.0 \mathrm{dS} / \mathrm{m}\right)$} \\
\hline & 1 & II & III & IV & Ort. & 1 & 11 & III & IV & Ort. \\
\hline $\begin{array}{l}\text { Çimlenen Tohum } \\
\text { Sayısı }\end{array}$ & 52 & 49 & 62 & 69 & 58.0 & 61 & 53 & 64 & 52 & 57.5 \\
\hline $\begin{array}{l}\text { Fide Boyu } \\
\text { (cm) }\end{array}$ & 13 & 14 & 17 & 17 & 15.3 & 16 & 16 & 18 & 19 & 17.3 \\
\hline
\end{tabular}

Çizelge 3. Fide biomas değerleri (\%).

\begin{tabular}{|c|c|c|c|c|c|c|c|c|c|c|c|}
\hline \multirow[t]{2}{*}{ Konu } & \multicolumn{11}{|c|}{ Tekrarlamalar } \\
\hline & 1 & II & III & IV & $\mathrm{V}$ & $\mathrm{VI}$ & VII & VIII & IX & $\bar{x}$ & Ort. \\
\hline$F_{0}=0.25$ & 90.1 & 89.3 & 91.0 & 90.1 & 90.1 & 91.3 & 90.1 & 88.0 & 87.7 & 88.6 & 89.63 \\
\hline$F_{1}=3.0$ & 89.2 & 89.1 & 89.3 & 89.1 & 90.0 & 88.9 & 90.7 & 90.8 & 90.1 & 90.5 & 89.77 \\
\hline
\end{tabular}




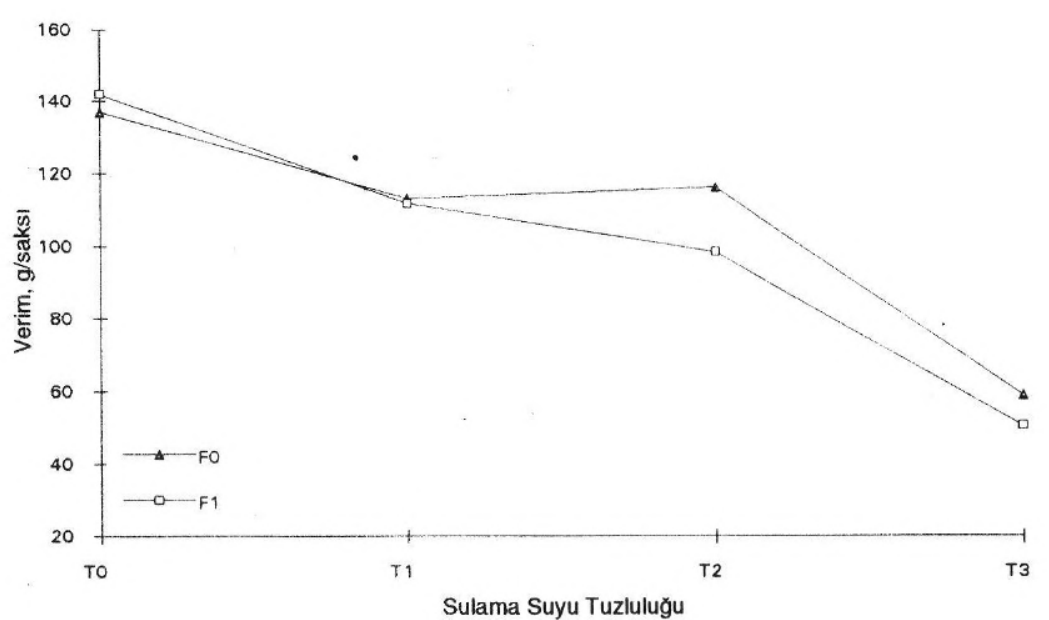

Şekil 1- Tuzluluk ile meyve verimi ilişkisi

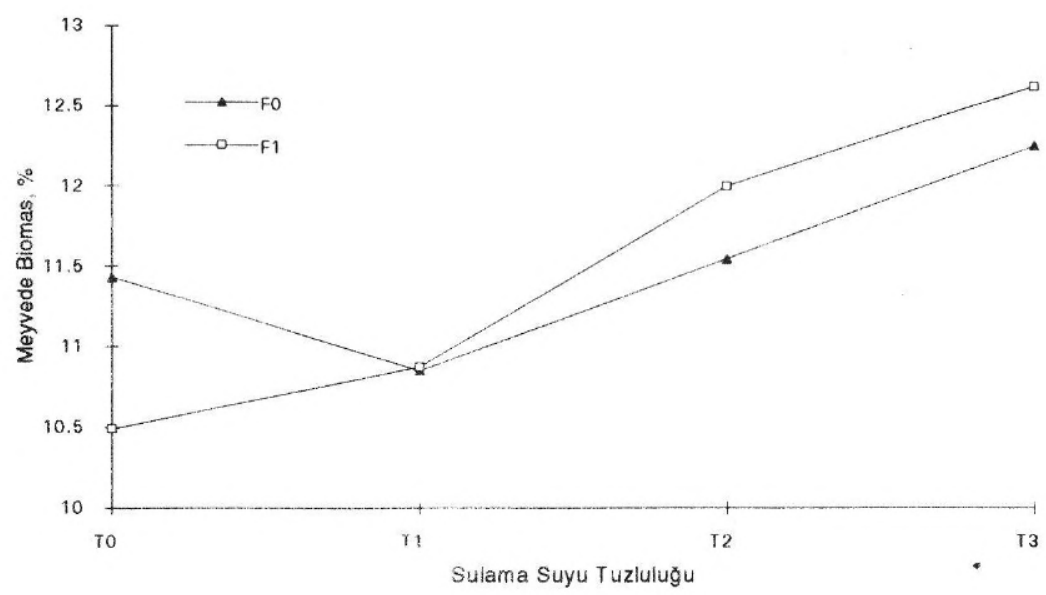

Şekil 3- Tuzluiuk ile meyvede biomas ilişkisi

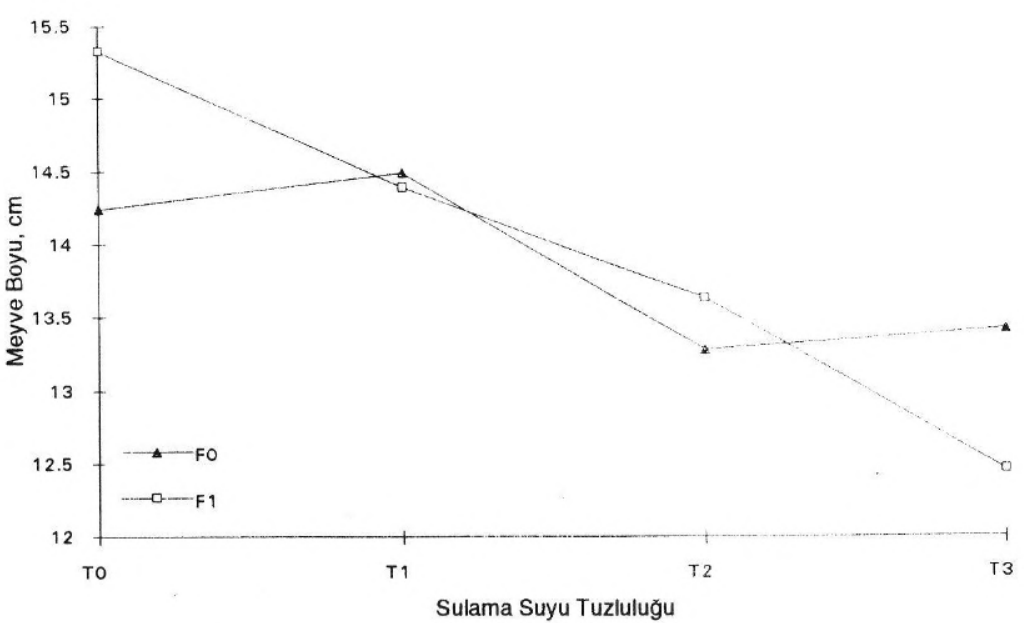

Şekil 2- Tuzluluk ile meyve boyu ilişkisi

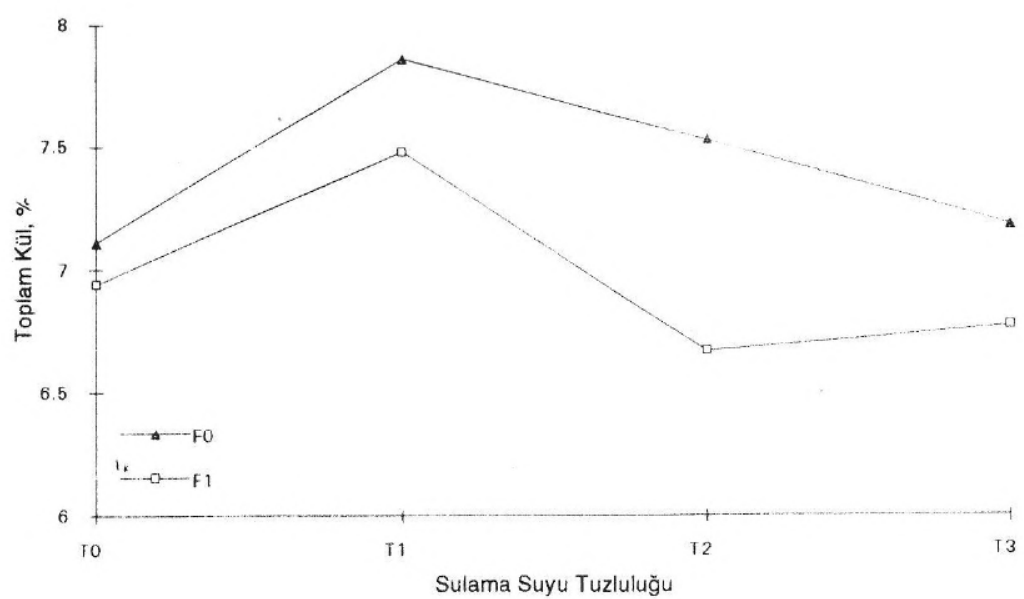

Şekil 4- Tuzluluk ile meyvede kül ilişkisi 
YURTSEVEN, E. ve ark., "Sulama suyu tuzluluğunun biberde (Capsicum annuum) farklı gelişme dönemlerinde bazı verim parametrelerine etkisi"

Çizelge 4. Tuzluluk konuları için meyve verimi, meyve boyu ve biomas değerleri.

\begin{tabular}{|c|c|c|c|c|c|c|c|}
\hline \multirow[t]{2}{*}{ Konu } & \multirow[t]{2}{*}{ Tekrariar } & \multicolumn{2}{|c|}{ Meyve Verimi(g/saksı) } & \multicolumn{2}{|c|}{ Meyve Boyu (cm) } & \multicolumn{2}{|c|}{ Meyvede Biomas (\%) } \\
\hline & & Toplam & Ort. & Toplam & Ort. & Toplam & Ort. \\
\hline \multirow[t]{3}{*}{$F_{0} T_{0}$} & 1 & 138.86 & \multirow[b]{3}{*}{137.06} & 12.95 & \multirow[b]{3}{*}{14.24} & 11.43 & \multirow[b]{3}{*}{11.43} \\
\hline & II & 135.48 & & 15.77 & & 10.90 & \\
\hline & III & 136.84 & & 14.00 & & 11.95 & \\
\hline \multirow[t]{3}{*}{$F_{0} T_{1}$} & 1 & 105.89 & \multirow[b]{3}{*}{113.02} & 13.01 & \multirow[b]{3}{*}{14.49} & 10.85 & \multirow[b]{3}{*}{10.85} \\
\hline & il & 110.36 & & 14.97 & & 10.81 & \\
\hline & III & 122.80 & & 15.50 & & 10.89 & \\
\hline \multirow[t]{3}{*}{$\mathrm{Ful}_{2}$} & 1 & 133.20 & \multirow[b]{3}{*}{115.99} & 13.79 & \multirow[b]{3}{*}{13.28} & 11.42 & \multirow[b]{3}{*}{11.54} \\
\hline & II & 82.51 & & 14.25 & & 12.68 & \\
\hline & III & 132.25 & & 11.79 & & 10.52 & \\
\hline \multirow[t]{3}{*}{$F_{0} T_{3}$} & 1 & 67.71 & \multirow[b]{3}{*}{58.98} & 14.08 & \multirow[b]{3}{*}{$13: 42$} & 12.07 & \multirow[b]{3}{*}{12.24} \\
\hline & II & 49.11 & & 12.91 & & 12.16 & \\
\hline & III & 60.11 & & 13.28 & & 12.48 & \\
\hline \multirow[t]{3}{*}{$F_{1} T_{0}$} & 1 & 133.96 & \multirow[b]{3}{*}{141.87} & 14.74 & \multirow[b]{3}{*}{15.33} & 10.65 & \multirow[b]{3}{*}{10.49} \\
\hline & II & 157.65 & & 15.13 & & 10.01 & \\
\hline & III & 134.00 & & 16.11 & & 10.82 & \\
\hline \multirow[t]{3}{*}{$F_{1} T_{1}$} & 1 & 124.51 & \multirow[b]{3}{*}{111.65} & 15.33 & \multirow[b]{3}{*}{14.39} & 11.28 & \multirow[b]{3}{*}{10.87} \\
\hline & II & 104.73 & & 13.89 & & 10.61 & \\
\hline & III & 105.71 & & 13.94 & & 10.74 & \\
\hline \multirow[t]{3}{*}{$F_{1} T_{2}$} & 1 & 81.82 & \multirow[b]{3}{*}{98.28} & 12.72 & \multirow[b]{3}{*}{13.63} & 11.71 & \\
\hline & II & 86.79 & & 13.65 & & 12.80 & \\
\hline & III & 126.22 & & 14.51 & & 11.45 & 11.99 \\
\hline$F_{1} T_{3}$ & 1 & 46.79 & & 12.33 & & 12.86 & \\
\hline & II & 52.12 & & 12.11 & & 12.76 & \\
\hline & III & 52.63 & 50.51 & 12.95 & 12.46 & 12.22 & 12.61 \\
\hline
\end{tabular}

Çizelge 5. Bitki verimi, meyve boyu ve meyve biomas değerleri duncan analizleri.

\begin{tabular}{|c|c|c|}
\hline Meyve Verimi & Meyve Boyu & Meyve Biomas \\
\hline$T_{0}=139.43 \mathrm{~A}$ & $T_{0}=14.78 \quad A$ & $T_{3}=12.43 \mathrm{~A}$ \\
\hline$T_{1}=112.33 \quad B$ & $T_{1}=14.44 \mathrm{AB}$ & $T_{2}=11.77 \mathrm{~A}$ \\
\hline$T_{2}=107.14 \quad B$ & $T_{2}=13.45 \quad B C$ & $T_{0}=10.96 \quad B$ \\
\hline$T_{3}=54.74$ & $T_{3}=12.94$ & $T_{1}=10.87$ \\
\hline
\end{tabular}

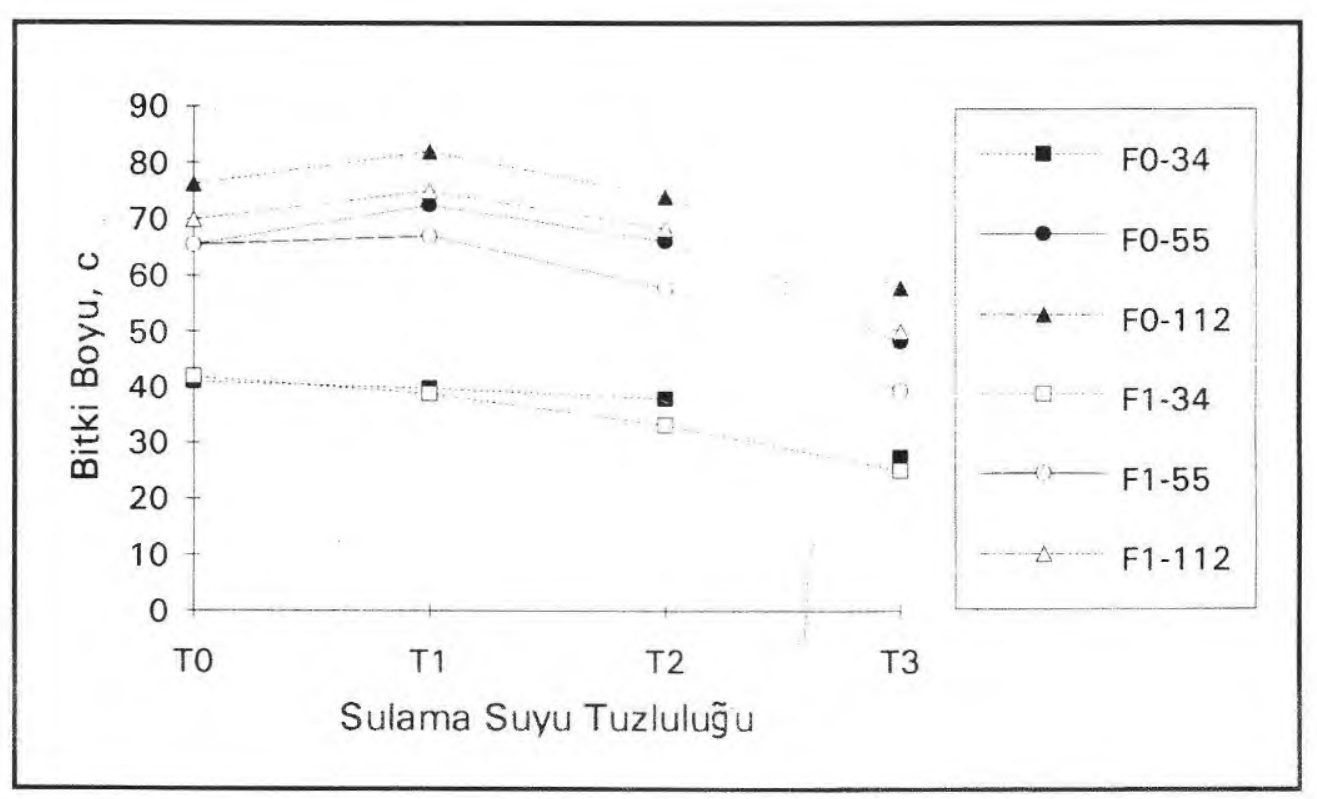

Şekil 5. Gelişme dönemi içerisinde 34., 55. ve 112. günierde ölçülen bitki boyları. 


\section{Sonuç}

Sivri biberde, çimlenme ve fide oluşumu dönemleri ile sonraki bitki gelişme dönemlerindeki sulama suyu tuzluluklarının, bazı verim parametreleri üzerine olan etkilerinin faktöriyel deneme düzeninde incelenmesi amacıyla planlanan ve sera koşullarında saksı denemeleri şeklinde yürütülen bu çalışmada; çimienme ve fide oluşumu dönemlerindeki iki tuzluluk düzeyi ile, sonraki gelişme dönemlerindeki 4 tuzluluk düzeyi, tesadüf parsellerinde faktöriyel denemeler biçiminde incelenmiştir. Biberde çimlenme üzerine $3 \mathrm{dS} / \mathrm{m}^{\prime} l i k$ tuzluluk düzeyi önemli bir etki oluşturmamıştır. Bir başka deyişle çimlenmede sulama suyu tuzluluğu bu düzeye kadar olumsuz bir etkide bulunmamıştır. Fide oluşumu üzerine ise fide boyunun artmasına neden olacak şekilde etki etmiştir. Fide biomas değerleri ise değişmemiştir. Yine çimlenme ve fide oluşumu dönemlerindeki tuzluluklar, sonraki bitki gelișmesi üzerine de herhangi bir etki yapmamıştır. Sonraki bitki gelişme döneminde göz önüne alınan sulama suyu tuzluluk düzeyleri ise bitki verimini azaltıcı etkide bulunmuşlardır. Tuzluluğun 0.25 $\mathrm{dS} / \mathrm{m}$ düzeyinden $6.0 \mathrm{dS} / \mathrm{m}$ düzeyine artması ile verimdeki azalma $\% 61$ düzeyine ulaşmıştır. Benzer şekilde meyve boylarında da \%13 kadar bir azalma gözlenmiştir. Bir diğer verim parametresi olan meyvedeki kuru madde düzeylerinde $\% 11$ kadar bir artma görülmektedir. Bu durum meyvedeki toplam kül miktarında görülen artma ile paraleldir. Toprak çözelti ortamında tuzluluğun artması ile meyvede biriktirilen mineral maddelerde de artma olmuştur. Bitki dal ve yapraklarında biriktirilen mineral madde miktarlarında ise bir farklılık gözlenmemiştir.

\section{Kaynaklar}

Anonymous, 1954. Diagnosis and Improvement of Saline and Alkali Soils. L.A. Richards (Ed.) U.S. Dept. of Agric., Agriculture Handbook No.60, Washington DC.

Ayers, R.. ve D.W. WESTCOT, 1989. Water Quality For Agriculture. FAO Irrigaion and Drainage Paper No.29, Rome.

Bouyoucos, G.J., 1951. A recalibration of the hydrometer method for making mechanical analyis of soils. Agron. J. 43:434-438.

Maas, E.V. ve G.J. Hoffman, 1977. Crop salt tolerance-Current assessment. J. Irrig. and Drain. Div., ASCE, 103(IR2):115134.

Özturk, A., 1994. Taban suyu derinliği ve sulama suyu kalitesinin biber verimine etkisi. A.Ü. Fen Bilimleri Enst. Tarımsal Yapılar ve Sulama Anabilim Dalı, Doktora (Basılmamış), Ankara.

Poonla, S.R. ve R. PAL, 1979. The effect of organic manuring and water quality on water transmission parameters and sodication of a sandy loam soil. Agric. Water Manage. 2:163-175

Smöth, P.T, ve B.G. Cobb, 1991. Accelerated germination of pepper seed by priming with salt solutions and water Hortiscience 26(4):417-419.

Sonneveld, C. ve A.V. Burg, 1991. Sodium chloride salinity in fruit vegetable crops in soilless culture. J. of Agricultural Sci., 39(2):115-122.

Yurtsever, N., 1984. Deneysel istatistik Metotlar. Toprak ve Gubre Araşt. Enst. Md. Yayınları Yay. No. 121/56, Ankara. 